\title{
Interrelationship between Philippine Stock Exchange Services Sector Index and Selected Macroeconomic Indicators
}

\author{
Eleazar B. San Miguel* \\ College of Business Administration Graduate School, Polytechnic University of the Philippines, \\ Philippines; sanmiguel.eleazar@yahoo.com
}

\begin{abstract}
Objectives: This study aims to analyze the relationship of the Philippine Stock Exchange Services Index price performance and selected macroeconomic indicators using its quarterly data, tracing the effect of independent to the dependent variable. Methods/Statistical Analysis: The researcher gathered the data from the Philippine Stock Exchange, Bangko Sentral Ng Pilipinas, Philippine Statistics Authority, and other reliable sources. These data are analyzed with the use of statistical correlation of the dependent and independent variables. The researcher also used linear regression to determine the most significant variables and remove the insignificant. Using the statistical tool paired T-test, the researcher was able to prove the predicted value of the Philippine Stock Exchange Services Index price performance. Findings: The quantitative analyzation showed that the foreign exchange rate (USDPHP), inflation rate, and real gross domestic product greatly affect the price performance of the sector index, while interest rate and unemployment rate were classified insignificant variables. Application/Improvements: This can offer a guide to investors to establish their ideal investment portfolio to maximize the possible growth of the index based on the factors correlated to the dependent variable.
\end{abstract}

Keywords: Economic Indicators, Index, Investment Portfolio, Philippine Stock Exchange Services Index, Price Performance

\section{Introduction}

The Philippine Stock Exchange has played a major role in every global economic upsurge linked up to other countries with a vast trading financial marketing system in which securities, commodities, and shares with companies can be purchased and sold 1 . The market sector indices show stock performance grouped by specific sectors of the market. This enables investors to benchmark the performance of a specific sector or industry in the stock market ${ }^{2}$.

The Philippines Stock Exchange's services sector is one of the country's sought-after stocks to invest in, and was one of the Philippine economy's strongest and fast-growing sector ${ }^{3}$. The sector index consists of companies that closely describe business activities related to media, telecommunications, information technology, transport, hotel and leisure, education, casinos and gaming, retail and other services that generate at least $60 \%$ or more of the company's revenue ${ }^{4}$.

Checking the constituents or companies that are grouped into this sector index and tracking their performance against the benchmark will help the investors in their investments decision making. Also, it is important to check the macroeconomic indicators of a country and how it will affect the fluctuation of the market specifically for the services sector. Appendix 1 provides the list of the current constituents of the index. This list may vary throughout the time and the current securities may not be part of the price performance calculation historically.

Volatility is the main concern of any investor in the stock market as their returns depend on the various

*Author for correspondence 
functions of the economic system. An economic analysis is a key to any investment decision making and quite often, stock market performance reflects the economy of that country and the other countries it is associated with ${ }^{5}$.

Previous studies showed different results and theories about the relationship between stock price performance and economic indicators.

$\mathrm{In}^{6}$ found that both the Philippine stock index and the unemployment rate had a significant positive and negative effect in one of the real gross domestic product economic indicators, respectively.

$\operatorname{In}^{7}$ study indicate that the price index is significantly affected by the inflation rate, savings interest rate, and foreign exchange rate and oil price.

$\mathrm{In}^{8}$ stated that there are systematic effects of macroeconomic variables on stock market returns. Any systematic variable affecting the economy also affects a single stock return and the return on the stock market as a whole.

$\mathrm{In}^{2}$ applied Granger causality test and pooled mean group estimator to derive long-term and shortterm statistical dynamics and show that the exchange rate has a positive and significant long-term effect on stock markets while inflation has a negative and insignificant effect. While in the short run, the relationship between macroeconomic variables and stock markets is not statistically significant.

The study for the Philippine Stock Exchange Composite Index shows that the best time series model for the Philippine Stock Exchange Composite Index is $\operatorname{ARIMA}(1,1,5)-\operatorname{ARCH}(1)$. Furthermore, the Consumer Price Index, crude oil price, and foreign exchange rate are factors concluded to Granger cause Philippine Stock Exchange Composite Index ${ }^{10}$.

This study is an addition to the existing literature. To the researcher's knowledge, the current research is the latest one focusing on the Philippine economy's services sector.

\subsection{Objective of the Study}

The aim of this study is to investigate the impact of macroeconomic indicators during the period 2006-2018 on the price performance of the PSE/Services sector index using multiple regression model and to determine to what extent the economic indicators do influence the index.

\subsection{Statement of the Problem}

This research is aimed at finding answers to the following key questions: What is the behavior of dependent and selected independent variables?

How do the major economic indicators of the Philippines contribute to stock market performance particularly the PSE Services Sector Index? Among the selected economic indicators, which are greatly affecting the performance of the sector index?

\subsection{Scope and Limitation}

This research covers the Philippines' major economic indicators and their impact on stock market performance over a 12-year period that is based on the Philippine Stock Exchange Services Sector Index's first trading date. The data are gathered from the relevant Philippine government agencies and other online sources that provide statistical records and economic data of the country. The model was designed to show how quarterly frequency economic indicators influence the sector index's performance.

\subsection{Significance of the Study}

The results of this empirical research can help the reader understand whether in some macroeconomic variables the price movement of the Philippine Stock Exchange Services Sector Index is subjected to change. This study will be a useful tool for investors to help them identify some basic economic variables that they should focus on while investing in the stock market and have an advantage in making investment decisions.

\subsection{Research Paradigm}

The Figure 1 shows the paradigm of the research. The Input - Process - Output Model was used, as seen from the figure, to diagram how the study came about and to ensure that it remains on track to address the issue.

\begin{tabular}{|c|c|c|}
\hline INPUT & PROCESS & OUTPUT \\
\hline $\begin{array}{l}\text { - Philippine Stock } \\
\text { Exchange Services } \\
\text { Sector Index } \\
\text { - Real Gross Domestic } \\
\text { Product } \\
\text { - Inflation Rate } \\
\text { - Unemployment Rate } \\
\text { - Interest Rate } \\
\text { - Foreign Exchange } \\
\text { (USDPHP) }\end{array}$ & $\begin{array}{l}\text { Pearson Correlation } \\
\text { Coefficient } \\
\text { Multiple Regression } \\
\text { Analysis }\end{array}$ & $\begin{array}{c}\text { Philippine Stock } \\
\text { Exchange Services } \\
\text { Sector Index Output } \\
\text { including predicted } \\
\text { value and significant } \\
\text { factors affecting its price } \\
\text { performance }\end{array}$ \\
\hline
\end{tabular}

Figure 1. Research Paradigm. 


\section{Methodology}

The study used a correlational approach to find which of the selected Philippine economic indicators affect the sector index price performance. A correlational study aimed at examining the covariance between two or more variables used. This statistical tool could determine if variables have a negative or positive relationship and the magnitude of the relationship given by the correlation coefficient between the variables being studied.

The data should come from the quarterly data of Real Gross Domestic Product (RGDP), Foreign Exchange Rate (ForEx), Unemployment Rate (UR), Interest Rate (IntR), Inflation Rate (InfR), and the price performance of PSE Services Index (PSX001) covering the year 2006 to 2018 coming from Bangko Sentral Ng Pilipinas (BSP), Philippine Stock Exchange (PSE), and Philippine Statistics Authority (PSA) and other online sources.

The data to be used and outputs of the analysis are going to be summarized and presented in tabular and graphical forms. The statistical analysis will be performed with the aid of Statistical Package for the Social Sciences (SPSS) and Microsoft Excel 2016 applications.

Generally, time-series data exhibit deterministic (past events affect the current events) and random trends. This implies that time-series data are mostly non-stationary. Various statistical tests will also be employed in the study. Multiple regression analysis will be used in the model development and forecasting process.

Below are the data used in calculating the statistical test mentioned above.

Table 1. Historical semi-annual data of the dependent and independent variables

\begin{tabular}{|c|c|c|c|c|c|c|}
\hline Date & $\begin{array}{c}\text { PSX } \\
\mathbf{0 0 1}^{\underline{11}}\end{array}$ & $\begin{array}{c}\text { RGD } \\
\mathbf{P}^{12}-\underline{13}\end{array}$ & $\begin{array}{c}\text { ForEx } \\
\text { (USD } \\
\mathbf{P H P}^{\underline{14}}\end{array}$ & $\begin{array}{c}\text { Int } \\
\mathbf{R}^{\underline{15}-} \\
\underline{16}\end{array}$ & $\mathbf{U R}^{\underline{17}}$ & $\begin{array}{c}\text { Inf } \\
\mathbf{R}^{\underline{18}}-\underline{19}\end{array}$ \\
\hline $06 / 30 / 2006$ & 1063.92 & 5.88 & 53.59 & 7.5 & 8.2 & 6.95 \\
\hline $12 / 29 / 2006$ & 1491.03 & 5.89 & 49.13 & 7.5 & 7.3 & 4.77 \\
\hline $06 / 29 / 2007$ & 1601.78 & 6.73 & 46.33 & 7.5 & 7.4 & 2.64 \\
\hline $12 / 31 / 2007$ & 1901.4 & 6.5 & 41.40 & 5.63 & 6.3 & 3.23 \\
\hline $06 / 30 / 2008$ & 1415.07 & 4.47 & 44.76 & 5.07 & 8 & 8.34 \\
\hline $12 / 31 / 2008$ & 1143.59 & 3.07 & 47.49 & 5.92 & 6.8 & 8.82 \\
\hline $06 / 30 / 2009$ & 1341.11 & 1.63 & 48.31 & 4.44 & 7.5 & 4.38 \\
\hline $12 / 31 / 2009$ & 1508.92 & 1.43 & 46.36 & 4 & 7.1 & 3.64 \\
\hline
\end{tabular}

\begin{tabular}{|c|c|c|c|c|c|c|}
\hline $06 / 30 / 2010$ & 1460.59 & 8.91 & 46.31 & 4 & 8 & 3.81 \\
\hline $12 / 31 / 2010$ & 1590.4 & 6.11 & 43.89 & 4 & 7.1 & 3.54 \\
\hline $06 / 30 / 2011$ & 1514.02 & 3.23 & 43.49 & 4.41 & 7.2 & 5 \\
\hline $12 / 30 / 2011$ & 1616.32 & 3.81 & 43.93 & 4.5 & 6.4 & 4.71 \\
\hline $06 / 29 / 2012$ & 1759.02 & 6.13 & 42.28 & 4 & 6.9 & 2.92 \\
\hline $12 / 31 / 2012$ & 1724.65 & 7.33 & 41.19 & 3.57 & 6.8 & 2.99 \\
\hline $06 / 28 / 2013$ & 1940.2 & 7.87 & 43.31 & 3.5 & 7.5 & 2.34 \\
\hline $12 / 31 / 2013$ & 1866.04 & 6.13 & 44.41 & 3.5 & 6.4 & 3 \\
\hline $06 / 30 / 2014$ & 2051.79 & 6.77 & 43.65 & 3.5 & 7 & 3.82 \\
\hline $12 / 31 / 2014$ & 2126.19 & 6.58 & 44.62 & 4 & 6 & 2.86 \\
\hline $06 / 30 / 2015$ & 2063.83 & 6.04 & 45.20 & 4 & 6.4 & 0.98 \\
\hline $12 / 31 / 2015$ & 1530.22 & 6.69 & 47.17 & 4 & 5.6 & 0.28 \\
\hline $06 / 30 / 2016$ & 1664.04 & 7.02 & 46.96 & 3.69 & 6.1 & 0.97 \\
\hline $12 / 30 / 2016$ & 1302.86 & 6.67 & 49.81 & 3 & 4.7 & 2.02 \\
\hline $06 / 30 / 2017$ & 1687.64 & 6.64 & 50.47 & 3 & 5.7 & 2.84 \\
\hline $12 / 29 / 2017$ & 1619.84 & 6.5 & 49.92 & 3 & 5 & 3.02 \\
\hline $06 / 29 / 2018$ & 1392.62 & 6.18 & 53.52 & 3.17 & 5.5 & 4.77 \\
\hline $12 / 31 / 2018$ & 1442.71 & 6.06 & 52.72 & 4.62 & 5.1 & 5.95 \\
\hline & & & & & & \\
\hline
\end{tabular}

Table 1 presents semi-annual data of the dependent variable (PSX001) and independent variables. Data shown were pulled directly from different websites and was sourced in BangkoSentral ng Pilipinas and Philippine Statistics Authority.

PSX001 - ticker of Philippine Stock Exchange Services Sector Index

RGDP - Real Gross Domestic Product

ForEx - Foreign Exchange

IntR - Interest Rate

UR - Unemployment Rate

InfR - Inflation Rate

\section{Results and Discussions}

The study aims to formulate a statistical model for the Philippine Stock Exchange Services Sector using multiple linear regressions. This part of the research Table 1 shows additional information on the behavior of the dependent and independent variables used, as well as several tests to determine the most important factors that contributed to the price performance of the PSE / Services Index, mathematical model in estimating the price performance, and significance of the difference between the actual value and predicted value of the price performance of the services index. 


\subsection{Graphical Behavior of the Dependent Variable and Independent Variables}

\subsubsection{Price Performance of Philippines Stock Exchange Services Sector}

Figure 2 shows the graph of the quarterly price performance of the Philippine Stock Exchange Services Sector from 2006 to 2018. It is evident that the price performance of the Philippine Stock Exchange Services Sector moves on the range of 1000php to 2200php. This can be reflected as the stable performance of the said industry within that price range.

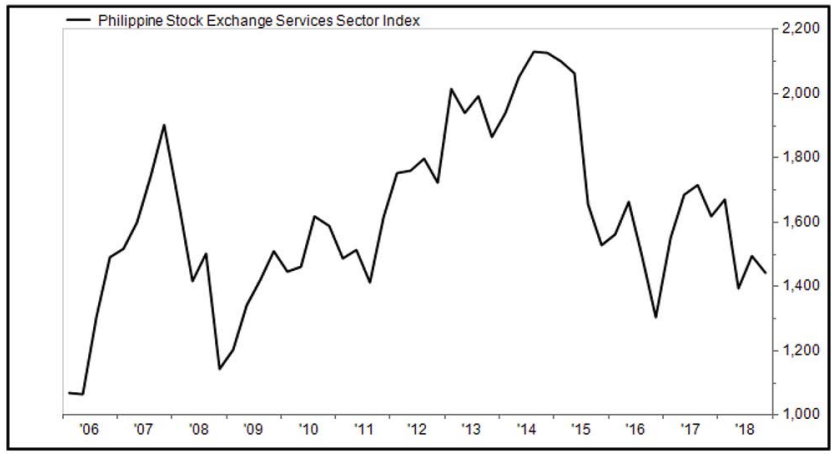

Figure 2. Price performance of PSE Services Sector index from 2006 to 2018 in Philippine peso.

The price performance of PSE Services has an upward trend from Q1 2006 to Q4 2007 with an increase of $77.5334 \%$, however, it declines from the period Q1 2008 to Q4 2008 decreased by $-31.0151 \%$. The index gains its strength on the period Q1 2009 to Q3 2014 where it reached the peak quarterly price performance of PhP2131.92, increase of 77.2951\%. Downtrend from Q4 2014 to Q4 2016, decreased of $-38.7233 \%$. For the most recent quarters Q1 2017 to Q3 2018, the sector index has stable moving price performance that is ranging to the amount of PhP1300 to PhP1750.

According to ASEAN reports, as of 2016, the Philippines have the second largest Gross Domestic Product (GDP) in Services Sector next to Singapore ${ }^{20}$. The services sector among the ASEAN countries has become an important and continually expanding supplier of both output and employment. This sector contributed over $40 \%$ of the total value added in the Philippines and other ASEAN countries over the period 2000-2007.And also, the sector accounted for over $40 \%$ of total employment in Singapore, Indonesia, Malaysia, and the Philippines in terms of employment $\stackrel{21}{ }$. The Philippines is widely recognized as one of the sources of high-quality workforce particularly in human resources, in services trade. The country is a net exporter of services due to a strong IT-BPM (Information Technology-Business Process Management) sector, particularly in the areas of legal, accounting, tax consulting, bookkeeping and auditing, business and management consultancy, engineering and computer and information services ${ }^{22}$.

\subsubsection{Real Gross Domestic Product (\%)}

Figure 3 shows the graph of the real gross domestic product from Q1 2006 to Q4 2018. It is can be seen on the graph that the real gross domestic product follows an unstable trend. This can be reflected in a variable real gross domestic product $\%$ of the country.

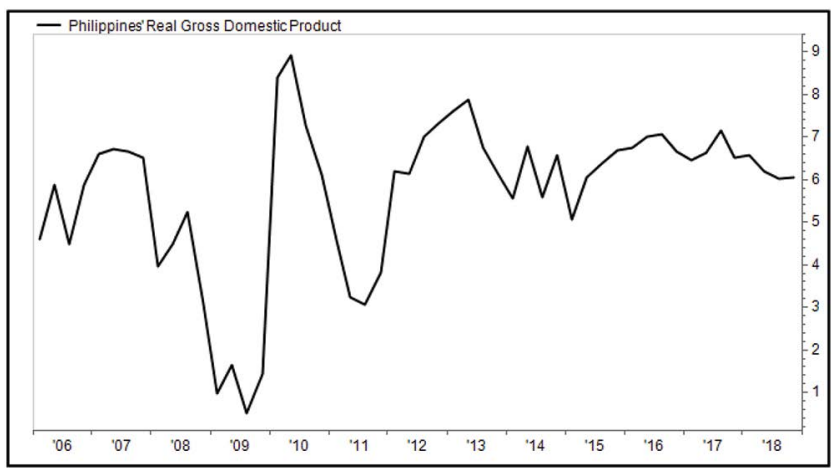

Figure 3. Real gross domestic product of the Philippines $\%$.

The 2008 Global Financial Crisis (GFC) caused the collapse of large financial institutions around the world; and contributed to the failure of various businesses, leading to significant economic downturns, particularly in the export sector in the Philippines. The Philippines recorded its lowest rate of RGDP at 0.52 on Q3 2009. It is the effect on the same period of the global financial crisis that occurred. The deadly storms (Typhoon "Ondoy") that crossed the country that dragged down the GDP rate were also cited by Philippine government officials ${ }^{23}$.

It is evident in the graph the upward trend on Q4 2009 to Q2 2010 where it records the 8.91 RGDP rate, an increase of $1620.44 \%$ compared to the lowest point 0.52 . The RGDP rate of the country drops again on the period Q3 2010 to Q3 2011 with the rate dips to 3.06, decreased of $-65.6853 \%$ compared to the peak 8.91 . The country's 
RGDP rate for the most recent quarters Q1 2012 to Q3 2018 shows stable performance with the range of 5.08 to 7.87. There's a small decrease from the period Q1 2012 to Q3 2018 of $-1.36897 \%$.

\subsubsection{Foreign Exchange Rate (USDPHP)}

Figure 4 shows the graph of the foreign exchange rate of Philippine peso to US dollars from Q1 2006 to Q4 2018. The movement of the exchange rate is unstable throughout the series. The lowest exchange rate was recorded on Q1 2013 with the amount of PhP40.81, while the highest exchange rate was recorded on Q3 2018 with the amount of PhP54.03.

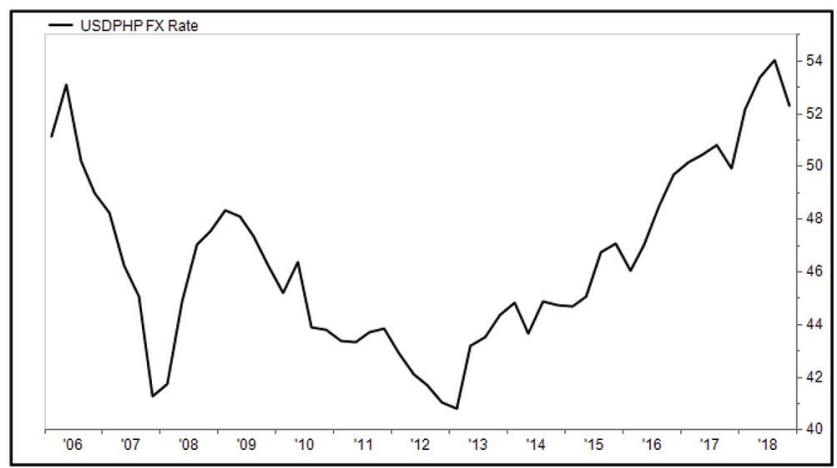

Figure 4. Foreign exchange rate (USDPHP).

During the last calendar year 2018, the Philippine peso continued to weaken. With the amount of PhP54.31 on September 25, 2018, the local currency reached its 13-year low Philippine Peso vs. US dollars. The "Build, Build, Build" infrastructure program of President Rodrigo Duterte and the growing domestic economy have increased the country's trade deficit to $\$ 22.49$ billion, 72 percent higher year-on-year, and led the country to depreciate the peso against the greenback ${ }^{24}$.

\subsubsection{Interest Rate (\%)}

Figure 5 shows the graph of the interest rate of the Philippines from Q1 2006 to Q4 2018. The movement of the points is a downward trend throughout the series.

The interest rate of the Philippines decreased from year Q1 2006 to Q2 2014, from 7.5 to 3.5 then, it increased $14.256 \%$ in the second quarter of 2014 to the first quarter of 2016. The country has a stable interest rate of 3.00 on the period Q3 2016 to Q1 2018. In the recent records, the interest increased again by $26.154 \%$ from the stable period with 3.00 to Q3 2018 with 3.78.

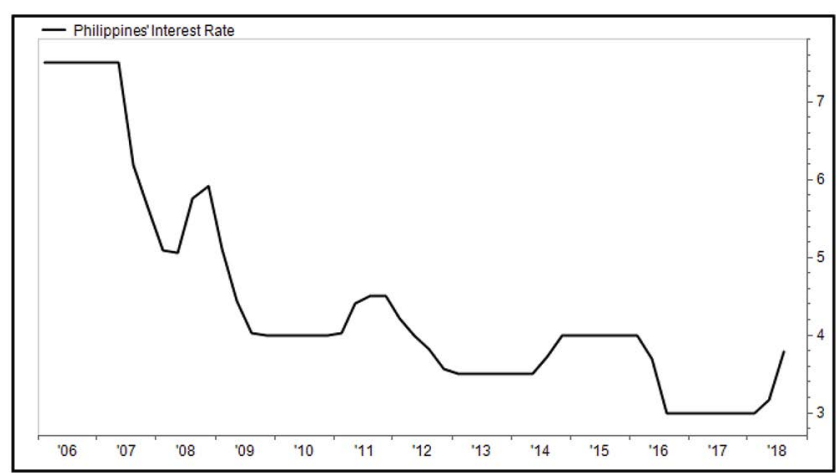

Figure 5. Interest rate of the Philippines \%.

In a bid to curb inflation and provide support to the local currency on Q3 of 2018, the Philippine central bank raised its policy rate to its highest level in nearly a decade. The Bangko Sentral Ng Pilipinas raised its benchmark rate to $4.5 \%$, its highest mark since March 2009, by 50 basis points. The BSP said it needed another strong monetary response to rein in expectations of inflation and to keep suppliers from passing on rising costs. BSP Deputy Gov. Chuchi Fonacier said policy rate hikes in 2018 "was warranted in the face of persistent signs of widening price pressures" and ease the Philippine peso pressure ${ }^{24}$.

\subsubsection{Unemployment Rate (\%)}

Figure 6 shows the graph of the unemployment rate of the Philippines from 2006 to 2018 on a quarterly frequency. The movement of the unemployment rate is variable downward throughout the series. A significant upsurge of the unemployment rate was apparent in the first quarter of 2017 with an increase of $40.4255 \%$.

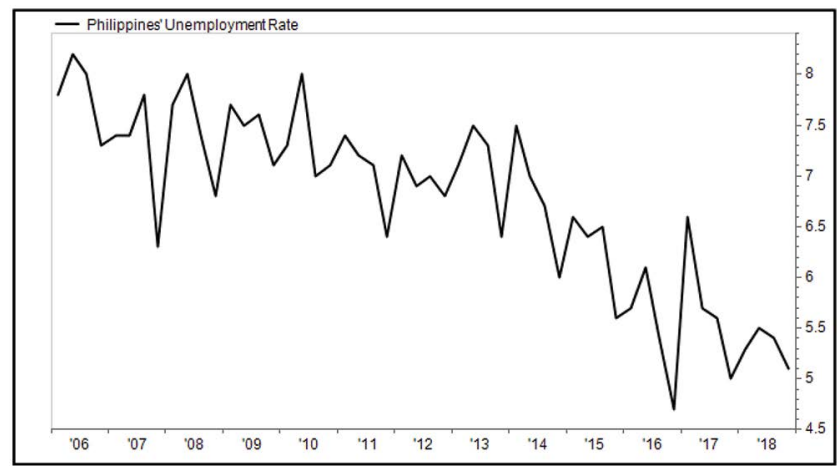

Figure 6. Unemployment rate of the Philippines \%.

Workers have been grouped into three broad sectors, namely the sector of agriculture, industry,and services. Services sector workers made up the largest proportion 
of the workforce. In January 2018, these workers made up 55.9 percent of the total workforce. Among them were those engaged in wholesale and retail trade; motor vehicle and motorcycle repair accounted for the largest percentage $(35.4 \%)$ of service sector workers. Workers in the service sector accounted for 57.1 percent of the total workforce in January 2017, with those engaged in wholesale and retail trade; motor vehicle repair and motorcycle repair representing the largest proportion of workers (35.2 percent).

Agricultural workers made up the second largest group, representing 26.0 percent of the total workforce in January 2018, while industrial workers made up the smallest group, accounting for 18.1 percent of the total workforce. In January 2017, agricultural workers accounted for $25.5 \%$ of the total workforce; while industry workers accounted for $17.4 \%$ of the total workforce. The results of the January 2018 Labor Force Survey(LFS) also showed that workers in the construction and manufacturing subsectors constituted the largest groups in the industry sector, representing 48.2 percent and 47.0 percent of workers in these subsectors respectively. The LFS uses a sample size of approximately 44,000 households.

Workers in the elementary occupations remained the largest group among the occupation groups, accounting for 27.6 percent of the total work in January 2018. Such workers accounted for 25.4 percent of the total employed in that period in January 2017. Managers comprised the second largest occupation group (16.3\%), followed in January 2018 by service and sales workers (14.7\%), and skilled agricultural, forestry and fishery workers $(13.1 \%)^{25}$.

\subsubsection{Inflation Rate (\%)}

Figure 7 exhibits the inflation rate of the Philippines from Q1 2006 to year end of 2018. The movement of the inflation rate of the country is unstable throughout the series. A significant upsurge in the inflation rate was apparent on the period of Q1 2008 to Q3 of the same year with the record high 10.28 rate on inflation of the country.

The higher inflation was largely attributed to rising food, utility, and transportation prices. Some tightness in domestic supply conditions associated with recent weather-related disturbances - resulting in some food items ' higher prices, particularly rice, meat, fish, and vegetables. The inflation rate of tobacco also rose due to

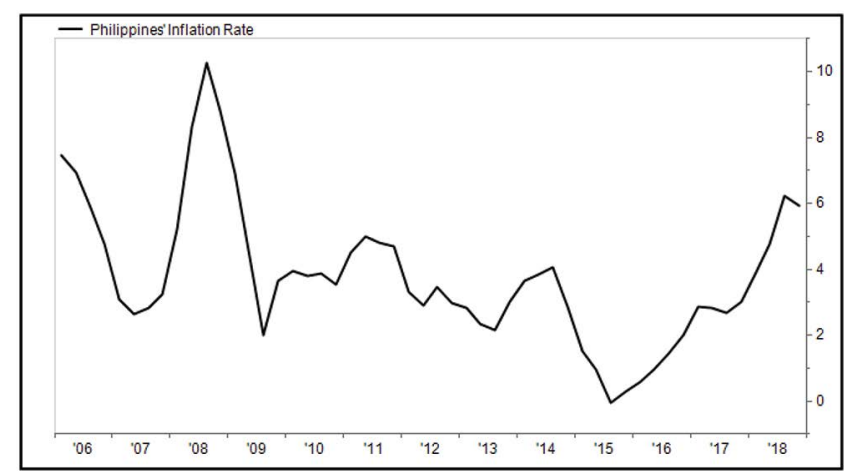

Figure 7. Inflation rate of the Philippines \%.

the planned increase in excise tax in July 2018. Similarly, the upward adjustment in electricity and water rates, as well as the temporary increase in the minimum jeepney tariffs, also contributed to the monthly increase in non food inflation ${ }^{26}$.

\subsection{Significance of the Relationship between the Price Performance of PSE Services Index and each of the Independent Variables}

The researcher conducted a Pearson correlation test to investigate the significance of the relationship between the PSE Services Index Price Performance and each of the independent variables. It is a statistical test measuring the relationship in statistics between two continuous variables. As it is based on the covariance method, it is known as the best way to measure the relationship between interest variables. It provides information about the magnitude of the relationship's correlation and direction ${ }^{27}$.

Table 2 depicts the relationship between the price performance of PSE Services Index and each of the independent variables. It can be seen on Table 2 that the independent variables such as Real Gross Domestic Product, Foreign Exchange Rate, Interest Rate, and Inflation Rate got a computed p-value of that is less than the level of significance 0.05 , therefore the null hypothesis is rejected, this implies that the price performance of the PSE Services Index and real gross domestic product has a moderate positive relationship having a Pearson coefficient value of 0.396 , while foreign exchange rate and inflation rate has a strong negative relationship having a Pearson coefficient value of -0.561 and -0.520 respectively, and the interest rate with Pearson coefficient value of -0.436 which has a negative moderate relationship. 
Table 2. Relationship between the price performance of PSE Services Sector index and of the independent variables

\begin{tabular}{|c|c|c|c|c|}
\hline \multirow{2}{*}{ Independent Variables } & \multicolumn{4}{|c|}{ Price Performance of PSE Services Index } \\
\hline & Pearson Coefficient & p-value & Decision & Remarks \\
\hline Real Gross Domestic Product & 0.396 & 0.0037 & Reject Ho & Significant \\
\hline $\begin{array}{l}\text { Foreign Exchange Rate } \\
\text { (USDPHP) }\end{array}$ & -0.561 & 0.0000 & Reject Ho & Significant \\
\hline Interest Rate & -0.436 & 0.0012 & Reject Ho & Significant \\
\hline Unemployment Rate & -0.147 & 0.2974 & Failed to Reject Ho & Not Significant \\
\hline Inflation Rate & -0.520 & 0.0001 & Reject Ho & Significant \\
\hline
\end{tabular}

Note: If p-value is less than or equal to the level of significance which is 0.05 reject the null hypothesis otherwise accept. Correlation coefficient values: $\pm 0.76- \pm 0.99$ Very Strong; $\pm 0.51- \pm 0.75$ Strong; $\pm 0.26- \pm 0.50$ Moderate; $\pm 0.11- \pm 0.25$ Weak; $\pm 0.01- \pm 0.10$ Very Weak.

The price performance of the PSE Services Index and the independent variable unemployment rate got a computed p-value of 0.2974 that is greater than the level of significance 0.05 , therefore the null hypothesis is accepted, this implies that the price performance of the PSE Services Index and unemployment rate have a negatively weak relationship having a Pearson coefficient -0.147 .

\subsection{Factors that Significantly Affect the Price Performance of PSE Services Index}

Table 3 shows the t-test is used in the multiple linear regression model to check the significance of individual regression coefficients. Adding a significant variable to a model of regression makes the model more effective while adding an insignificant variable can make the model worse ${ }^{28}$.
On the other hand, the p-value of independent variable Interest Rate $(0.0520)$ is more than 0.05 level of significance, indicating that the regression coefficient is not significant, and should be removed in the model.

\subsection{Mathematical Model in Estimating the Price Performance of PSE Services Index}

Before considering the model in estimating the price performance of PSE Services Index, the assumptions must be satisfied first.

\subsubsection{Testing Assumptions}

The assumptions of multiple linear regression are normality, linear relationship between the

Table 3. Individual test of significance of regression coefficients

\begin{tabular}{|l|c|c|c|c|c|}
\hline \multicolumn{1}{|c|}{ Independent Variable } & Regression Coefficient & t-value & p-value & Decision & Remarks \\
\hline Constant & 3240.5822 & 8.7844 & 0.0000 & Reject Ho & Significant \\
\hline $\begin{array}{l}\text { Foreign Exchange Rate } \\
\text { (PHPUSD) }\end{array}$ & -36.1599 & -4.6156 & 0.0000 & Reject Ho Significant \\
\hline Inflation Rate & -38.7465 & -2.7969 & 0.0074 & Reject Ho & Significant \\
\hline $\begin{array}{l}\text { Real Gross Domestic } \\
\text { Product }\end{array}$ & 35.6873 & 2.2699 & 0.0277 & Reject Ho Significant \\
\hline Interest Rate & & -1.9910 & 0.0520 & $\begin{array}{c}\text { Failed to Reject } \\
\text { Ho }\end{array}$ & Not Significant \\
\hline
\end{tabular}

Table 3 presents the individual test of the significance of regression coefficients for the full model. It can be observed from the table that the p-values of independent variables Foreign Exchange Rate (0.0000), Inflation Rate (0.0074), and Real Gross Domestic Product (0.0277) are less than 0.05 level of significance, indicating that their regression coefficients are significant and should be retained in the model. 
outcome variable and the independent variables, no multicollinearity, independence, and homoscedasticity ${ }^{29}$. The model underwent several tests to ensure that the assumptions were satisfied.

\subsubsection{Mathematical Models in Predicting the} Price Performance of PSE Services Index

$\mathrm{Y}=3240.5822 b_{0}-36 \mathrm{~S} .1599 b^{1}-38.7465 b_{2}+35.6873 b_{3}$

The researcher used three (3) independent variables

-- foreign exchange rate, inflation rate, and real gross domestic product -- to predict the dependent variable price performance of the Philippine Stock Exchange Services Index. Using the matrix above, the researcher formed a regression model that can predict the price performance of the index.

Table 4 presents the MAPE measures the forecasting error of the reduced regression model ${ }^{30}$, the value indicates that the forecasts are off by $8.9903 \%$ of the actual value of price performance of PSE Services Index; the MAE (Mean Absolute Error) or the average expected error $\frac{31}{1}$ is 145.1512; the MSPE (Mean Square Prediction Error) which depicts the spread out of the residuals 32 is 32646.7262; and the RMSPE (Root Mean Square Prediction Error) which measures the deviation of data from the regression line ${ }^{33}$ is 180.6841 .

Table 4. MAPE, MAE, MSPE, and RMSPE

\begin{tabular}{|l|l|}
\hline $\begin{array}{l}\text { Mean Absolute Percentage Error } \\
\text { (MAPE) }\end{array}$ & $8.9903 \%$ \\
\hline Mean Absolute Error (MAE) & 145.1512 \\
\hline Mean Square Prediction Error (MSPE) & 32646.7262 \\
\hline $\begin{array}{l}\text { Root Mean Square Prediction Error } \\
\text { (RMSPE) }\end{array}$ & 180.6841 \\
\hline
\end{tabular}

\subsection{Significance of the Difference between the} Actual Value and Predicted Value of the Price Performance of PSE Services Index

The paired sample t-test is a statistical procedure used to determine if the mean difference between two sets of observations is zero. Every subject or entity is measured twice in a paired sample t-test, resulting in pairs of observations ${ }^{34}$.

Table 5 shows the significance of the difference between the actual value and the predictedvalue of the price performance of the index from 2006 to 2018 using the paired $\mathrm{t}$-test. It was revealed from the table that the actual value of price performance from 2006 to 2018 with mean 1616.9173 and predicted value with mean 1616.9173 does not have a significant difference. The computed t-value 0.654 has a $p$-value 0.580 which is greater than 0.05 level of significance, indicating failed to reject the null hypothesis.

\section{Conclusion and Recommendations}

From the results of statistical tests, it can be concluded that macroeconomic indicators such as the real gross domestic product, inflation rate, and foreign exchange rate have a strong relationship on the price performance of the PSE Services Sector Index constituents, while interest rate and unemployment rate have no significant relationship with the dependent variable. Both the various inferential statistical findings support this conclusion.

While this study provided conclusive statements, there are other factors that would need to be considered by an investor in their investment decisions. First, the companies belonging to the index. To build trust and confidence in investing, it is important to check the internal policies and management of each company. It needs to consider also the unforeseen events, such as calamities that are not controlled by the market, and other events such as political risks, and others.

In view of these limitations, the result should not be seen as conclusive evidence, but rather as a drive for further research in this area. The author recommends further inclusion of future observations in comparison with the future values of the price performance of the Philippine Stock Exchange Services Sector Index and the

Table 5. Paired T-test: Significant difference between actual value and predicted value

\begin{tabular}{|l|c|c|c|c|c|}
\hline $\begin{array}{c}\text { Price Performance of the PSE } \\
\text { Services Index, 2006-2018 }\end{array}$ & Mean & t-value & p-value & Decision & Remarks \\
\cline { 1 - 2 } Actual Value & 1616.9173 & 0.000 & 1.000 & $\begin{array}{c}\text { Failed to Reject } \\
\text { Ho }\end{array}$ & Not Significant \\
\hline Predicted Value & 1616.9173 & &
\end{tabular}


selected macroeconomic indicators. This can be the use of stock market analysts, brokers, investors, and managers to increase their portfolio investment returns further.

\section{Appendix}

\section{Companies that constitutes Philippine Stock Exchange Services Sector Index}

As of June 19, 2019, below are the constituents of the Philippines Stock Exchange Services Sector Index (PSX001):

- ABS-CBN Corporation

- Bloomberry Resorts Corporation

- Cebu Air Inc.

- Chelsea Logistics \& Infrastructure Holdings Corp.

- Globe Telecom Inc.

- GMA Network, Inc.

- Harbor Star Shipping Services, Inc.

- International Container Terminal Services, Inc.

- Leisure \& Resorts World Corp.

- MacroAsia Corp.

- Metro Retail Stores Group, Inc.

- Now Corporation

- Philippine Seven Corporation

- Philweb Corporation

- PLDT, Inc.

- Premium Leisure Corp.

- Puregold Price Club Inc.

- Robinsons Retail Holdings, Inc.

- SSI Group Inc

- STI Education Systems Holdings, Inc.

- Transpacific Broadband Group International, Inc.

- Waterfront Philippines, Inc.

- Wilcon Depot, Inc.

Source: PSE $\underline{35}$

\section{Acknowledgements}

The author would like first to thank the Almighty God who gave wisdom and determination. And to Mr. Wilfredo O. Pascual Jr. for the encouragement and valuable effort to check my drafts from time to time.

\section{References}

1. Urrutia JD, Diaz JLB, and Baccay EB. Forecasting Philippine Daily Stock Exchange Index. J Fundament Appl Sci. 2017; 9(7S): 202-218.
2. Market Sector Indices [internet]. https://www.nasdaq.com/ markets/indices/sector-indices.aspx. Date accessed: 2019.

3. Securing the Future of the Philippine Industries [internet]. http://industry.gov.ph/category/services/. Date accessed: 2019.

4. PSE Circulars Revised Policy on Index Management [internet]. https://pse.com.ph/stockMarket/circulars.html. Date accessed: 2019.

5. Sanningammanavara K, Kumar KVK. Economic Indicators and Stock Market Performance - An Empirical Case of India. Int. J. Manag. 2014; 5(8): 107-114.

6. Balaba JM. Does the Stock Market Drive the Philippine Economy? Paper presented at: DLSU Research Congress. 2017; $1-6$.

7. Is There a Synchronicity Between the Philippine Stock Exchange and New York Stock Exchange? [internet]. https://ideas.repec.org/a/ibf/ijbfre/v3y2009i1p69-77.html. Date accessed: 2009.

8. The Effect of Economic Factors on the Performance of the Australian Stock Market [internet]. http://vuir.vu.edu. au/19400/1/Riza_Erdugan.pdf. Date accessed: 02/2012.

9. Macroeconomic indicators and their impact on stock markets in ASIAN 3: A pooled mean group approach [internet]. https://www.tandfonline.com/doi/full/10.1080/ 23322039.2018.1432450. Date accessed: 2018.

10. Modeling Philippine Stock Exchange Composite Index Using Time Series Analysis. https://iopscience.iop.org/ article/10.1088/1742-6596/622/1/012022. Date accessed: 2015.

11. The Philippine Stock Exchange Index History [internet]. https://www.pse.com.ph/stockMarket/marketInfomarketActivity.html?tab=1\&indexName=Services. Date accessed: 2012.

12. Rivas R. Philippine Economy Slows Down to 6\% in Q2 2018 [internet]. https://www.rappler.com/business/209165gross-domestic-product-philippines-q2-2018. Date accessed: 2018.

13. Philippines GDP Annual Growth Rate. https:// tradingeconomics.com/philippines/gdp-growth-annual. Date accessed: 2019.

14. Reference Exchange Rate Bulletin [internet]. http://www. bsp.gov.ph/statistics/statistics_exchrate.asp. Date accessed: 21/06/2019.

15. Statistics [internet]. http://www.bsp.gov.ph/statistics/efs_ fsa1.asp. Date accessed: 2015.

16. Philippine Interest Rate [internet]. https:// tradingeconomics.com/philippines/interest-rate. Date accessed: 2019.

17. Philippine Unemployment Rate [internet]. https://www. ceicdata.com/en/indicator/philippines/unemploymentrate. Date accessed: 2019.

18. Bueza M. Fast Facts: Philippine Inflation Rate over the Years [internet]. https://www.rappler.com/newsbreak/ 
fast-facts/213604-things-to-know-philippine-inflationover-the-years. Date accessed: 10/10/2018.

19. Philippine Inflation Rate [internet]. https:// tradingeconomics.com/philippines/inflation-cpihttps:// www.rappler.com/newsbreak/fast-facts/213604-things-toknow-philippine-inflation-over-the-years. Date accessed: 2019.

20. Trade Services in ASEAN [internet]. https://asean.org/ asean-economic-community/sectoral-bodies-under-thepurview-of-aem/services/. Date accessed: 2016.

21. The ASEAN Services Sector and Growth Rebalancing Model [internet]. https://www.adb.org/sites/default/ files/publication/156101/adbi-wp246.pdf. Date accessed: $09 / 2010$.

22. The Philippine Services Sector and APEC [internet]. https:// www.neda.gov.ph/wp-content/uploads/2015/11/APECprimer-on-services_comp4.pdf. Date accessed: 2015.

23. GDP growth at $0.9 \%$ in 2009 vs $3.8 \%$ a year ago [internet]. https://news.abs-cbn.com/business/01/28/10/philippinegdp-growth-09-2009-vs-38-year-ago. Date accessed: 28/01/2010.

24. Philippine Interest Rates Reach Highest Mark in a Decade [internet]. https://asia.nikkei.com/Economy/Philippineinterest-rates-reach-highest-mark-in-a-decade. Date accessed: 27/09/2018.

25. Employment Rate in January 2018 is Estimated at 94.7 Percent. https://psa.gov.ph/content/employment-ratejanuary-2018-estimated-947-percent. Date accessed: 07/03/2018.

26. July Inflation Higher at 5.7 Percent [internet]. http:// www.bsp.gov.ph/publications/media.asp?id=4766. Date accessed: 08/07/2018.
27. Pearson's Correlation Coefficient [internet]. https://www. statisticssolutions.com/pearsons-correlation-coefficient/. Date accessed: 2019.

28. T-Test Definition [internet]. https://www.investopedia. com/terms/t/t-test.asp. Date accessed: 21/05/2019.

29. Assumptions of Multiple Linear Regression [internet]. https://www.investopedia.com/terms/t/t-test.asphttps:/ www.statisticssolutions.com/assumptions-of-multiplelinear-regression. Date accessed: 2019.

30. Forecasting 101: A Guide to Forecast Error Measurement Statistics and How to Use Them. https://www.forecastpro. com/Trends/forecasting101August2011.html. Date accessed: 2019.

31. MAE and RMSE - Which Metric is Better? [internet]. https://medium.com/human-in-a-machine-world/maeand-rmse-which-metric-is-better-e60ac3bde13d. Date accessed: 23/03/2016.

32. Mean Squared Prediction Error. https://en.wikipedia.org/ wiki/Mean_squared_prediction_error. Date accessed: 06/06/2019.

33. What is Root Mean Square Error (RMSE)? [internet]. https://www.statisticshowto.datasciencecentral.com/rmse/. Date accessed: 2016.

34. Paired Sample T-Test [internet]. https://www. statisticssolutions.com/manova-analysis-paired-sample-ttest/. Date accessed: 2019.

35. The Philippine Stock Exchange Indices Composition [internet]. https://www.pse.com. $\mathrm{ph} / \mathrm{s}$ tockMarket/market Info-market Activity. html?tab=1\&indexName=Services. Date accessed: 21/06/2019. 